\title{
Registration of three soft red winter wheat germplasm lines with exceptional milling and cookie baking performance
}

\author{
Nicholas A. Meier ${ }^{1}$ @ | Subas Malla ${ }^{2}$ \\ Joseph C. Oakes ${ }^{3}$ \\ J. Paul Murphy ${ }^{4}$ \\ Byung-Kee Baik $^{5}$ | Shiaoman Chao ${ }^{6}$ \\ Carl A. Griffey ${ }^{1} \odot$
}

\author{
${ }^{1}$ School of Plant and Soil Environmental \\ Sciences, Virginia Tech, Blacksburg, VA \\ 24060, USA \\ ${ }^{2}$ Texas A\&M AgriLife Research \& \\ Extension Center, Uvalde, TX 78801, USA \\ ${ }^{3}$ Eastern Virginia Agricultural Research \\ and Extension Center, Virginia Tech, \\ Warsaw, VA 22572, USA \\ ${ }^{4}$ Dep. of Crop Science, North Carolina \\ State Univ., Raleigh, NC 27695, USA \\ ${ }^{5}$ USDA-ARS Soft Wheat Quality \\ Laboratory, Wooster, OH 44691, USA \\ ${ }^{6}$ USDA-ARS Cereal Crops Research Unit, \\ Fargo, ND 58102, USA

\section{Correspondence} \\ Nicholas A. Meier, School of Plant and Soil \\ Environmental Sciences, Virginia Tech, \\ Blacksburg, VA 24060, USA. \\ Email:namvf6@vt.edu \\ Registration by CSSA.
}

\begin{abstract}
The release of soft red winter wheat (Triticum aestivum, L.) germplasm lines VA11DH-P46xTrib-28 (Reg. no. GP-1048, PI 691656), VA11DH-P46xTrib-99 (Reg. no. GP-1049, PI 691657), and VA11DH-P46xTrib-103 (Reg. no. GP-1050, PI 691658) is intended to provide breeders with genetic material having exceptional milling and baking quality performance. The quantitative nature of milling and baking performance makes improvement and early generation selection difficult. Marker assisted and genomic selection breeding schemes can be improved by introducing breeding material with superior end-use quality and use of known predictive DNA markers. These three lines have acceptable agronomic performance with grain yields $\left(4605-5733 \mathrm{~kg} \mathrm{ha}^{-1}\right)$ similar to or higher than those of Pioneer '26R46' (4568 $\left.\mathrm{kg} \mathrm{ha}^{-1}\right)$. The lines have exceptional milling and baking performance with mean flour yields (733-736 $\mathrm{g} \mathrm{kg}^{-1}$ ), softness equivalence (550$573 \mathrm{~g} \mathrm{~kg}^{-1}$ ), flour protein (89-94 $\mathrm{g} \mathrm{kg}^{-1}$ ), solvent retention capacity for lactic acid (1162-1189 $\mathrm{g} \mathrm{kg}^{-1}$ ) and sodium carbonate (672-697 $\left.\mathrm{g} \mathrm{kg}^{-1}\right)$, and cookie diameters $(19.1-19.5 \mathrm{~cm})$ that are better than or similar to $(p<.05)$ those of Pioneer 26R46 (721 $\mathrm{g} \mathrm{kg}^{-1}, 531 \mathrm{~g} \mathrm{~kg}^{-1}, 93 \mathrm{~g} \mathrm{~kg}^{-1}, 1221 \mathrm{~g} \mathrm{~kg}^{-1}, 703 \mathrm{~g} \mathrm{~kg}^{-1}$, and $18.9 \mathrm{~cm}$ ).
\end{abstract}

\section{1 | INTRODUCTION}

End-use quality of soft red winter wheat (SRWW, Triticum aestivum, L.) germplasm is generally only considered by breeders once pure lines have been selected and tested in yield trials and sufficient grain is available for quality testing. Other than choosing parents and crosses to make, SRWW breeders focus most of their initial efforts on line selection and evaluation of pure lines for grain yield, test weight, and disease resistance, particularly Fusarium

\footnotetext{
Abbreviations: AACC, American Association of Cereal Chemists; BLUP, best linear unbiased predictor; DH, doubled haploid; DON, deoxynivalenol; FHB, Fusarium head blight; QTL, quantitative trait loci; SRWW, soft red winter wheat.
}

head blight (Fusarium graminearum Schwabe) (FHB), as these traits are the most economically relevant to growers and are routinely assessed by breeders in the field. End-use quality is comprised of multiple physical and compositional grain traits that are difficult and costly to measure (Posner \& Hibbs, 2005). Grain traits associated with end-use quality are under quantitative genetic control and influenced by environmental conditions. Flour yield and cookie diameter, the most critical soft wheat milling and baking quality parameters, are correlated traits and are moderately to highly heritable (Souza et al., 2012). Cookie diameter tends to increase with flour yield, while it decreases with increasing solvent retention capacity, kernel hardness, and flour protein. This is predictable—as the 
pressure required to crush the wheat kernel increases so does starch damage, which negatively influences cookie diameter. Kernels containing higher levels of protein are generally harder in texture and require more pressure to crush during milling, thus resulting in lower break flour extraction and small cookie diameters (Smith et al., 2011).

Breeding for end-use quality per se, solely on the basis of phenotypic data for multiple quality traits, is difficult due to the quantitative nature of these traits and lack of reliable high-throughput markers to aid in selection of parents and progeny on the basis of quality. Quantitative trait loci (QTL) for wheat milling and baking performance have been reported on all 21 chromosomes (Breseghello \& Sorrells, 2006; Cabrera et al., 2015; Li, Song, Zhou, Branlard, \& Jia, 2009; Souza et al., 2012). However, markers associated with most of these QTL are not routinely deployed in breeding programs, and thus genetic gains for improved quality remain stagnant (Kiszonas \& Morris, 2017). A complementary approach to marker assisted or genomic selection is to introduce superior end-use quality transgressive segregates from breeding populations with the aid of predictive genetic markers to help facilitate genetic improvement of traits that influence milling and baking performance. The release of VA11DH-P46xTrib-28 (Reg. no. GP1048, PI 691656), VA11DH-P46xTrib-99 (Reg. no. GP-1049, PI 691657), and VA11DH-P46xTrib-103 (Reg. no. GP-1050, PI 691658) germplasm lines is intended to provide SRWW breeders with breeding material that has superior end-use quality in an effort to help improve milling and baking performance in future SRWW cultivars.

\section{2 | METHODS}

\subsection{Development of lines}

These SRWW germplasm lines were identified as transgressive segregates in a doubled haploid (DH) population designed to map QTL associated with milling and baking quality performance. The doubled haploid lines were derived from the cross Pioneer '26R46' (PI 612154) by 'Tribute' (PI 632689) (Griffey et al., 2005). Doubled haploid production was conducted in collaboration with J. Paul Murphy at North Carolina State University in Raleigh, NC. A total of 112 full sib DH lines were developed from this cross and screened for milling and baking quality performance. The cultivar Tribute was derived from the cross VA92-51-39/AL870365. Pioneer 26R46 was derived from the cross FL7927-G14//Pioneer '2555' (PI 532914)*3/'Coker 8028'. Both Pioneer 26R46 and Tribute are photoperiod insensitive (Ppd-D1a) and lack the Bx7 over-expression glutenin allele at Glu-B1 and TaSus2-2B, while both have the 5+10 glutenin subunits (Glu-D1). Tribute possesses the 1RS:1AL rye (Secale cereale) translocation (Table 1). On average across three site-years, Tribute had grain yields that were 9\% higher, it is $3 \mathrm{~cm}$ taller in plant height, and reached maturity $2 \mathrm{~d}$ later than Pioneer 26R46 (Table 2).

\section{2 | Field test evaluations}

Complete management information is included in Table 3. Each DH line, the parents, and adapted checks were grown in yield plots comprised of seven rows spaced $15.24 \mathrm{~cm}$ apart with a total harvested area of 1.5 by $2.7 \mathrm{~m}$. All seeds were coated with Gaucho-XT (Imidacloprid, Bayer Crop Science) insecticide and Raxil MD (tebuconazole and metalaxyl, Bayer Crop Science) fungicide seed treatments. Fall nutrient management and spring $\mathrm{N}$ applications were based on standard local management practices (Brann, Holshouser, \& Mullins, 2000) and recommendations from the Virginia Cooperative Extension Soil Testing Service. Plots were managed for optimum quality in consideration of local conditions, including foliar fungicide applications (Table 3). Tests were grown at Kentland Research Farm $\left(37^{\circ} 11^{\prime} 45^{\prime \prime} \mathrm{N}, 80^{\circ} 34^{\prime} 28^{\prime \prime} \mathrm{W}\right)$ near Blacksburg, VA, during the 2016-2017 growing season and in fields at the Eastern Virginia Agriculture Research and Extension Center $\left(37^{\circ} 59^{\prime} 16^{\prime \prime} \mathrm{N}, 76^{\circ} 46^{\prime} 48^{\prime \prime} \mathrm{W}\right)$ near Warsaw, VA, during the 2015-2016 and 2016-2017 growing seasons.

\section{3 | End-use quality evaluations}

All grain samples were thoroughly air aspirated prior to testing to remove any dust or chaff. Test weight $\left(\mathrm{kg} \mathrm{hl}^{-1}\right)$ of wheat grain was determined according to Method 5510.01 (American Association of Cereal Chemists, 1999). Kernel weight (mg), hardness, and diameter ( $\mathrm{mm}$ ) were determined using the Single Kernel Characterization System (SKCS, Perten Instruments) according to Method 5531.01 (American Association of Cereal Chemists, 1999) as the averages of 300 kernels. Wheat grain protein $\left(\mathrm{g} \mathrm{kg}^{-1}\right)$ and moisture (\%) for tempering were estimated using a DA 7200 near-infrared analyzer (Perten Instruments). Wheat grain was tempered to $15 \%$ moisture for $24 \mathrm{~h}$ and milled using a modified Quadrumat Senior milling system to determine milling quality and to obtain flour. Flour yield $\left(\mathrm{g} \mathrm{kg}^{-1}\right)$ was the fraction of milled products that comprises the break and reduction flour after milling and calculated as [(grain weight - bran weight)/grain weight] $\times 100$. Softness equivalence $\left(\mathrm{g} \mathrm{kg}^{-1}\right)$ was calculated as (break flour/total flour) $\times 100$ (Finney \& Andrews, 1986). Flour protein was estimated using a near-infrared analyzer (Unity Spectra-Star). Lactic acid and $\mathrm{Na}_{2} \mathrm{CO}_{3}$ solvent retention capacities of the flour were determined 
TA B L E 1 Parental and doubled haploid (DH) line genotypes for major genes and quantitative trait loci associated with end-use quality in SRW wheat

\begin{tabular}{|c|c|c|c|c|c|}
\hline Parent or DH line & 1RS rye translocations & Glu-B1 & Glu-D1 & Ppd-D1 & TaSus2-2B \\
\hline Pioneer 26R46 & non-1RS & no & $5+10$ & insensitive & no \\
\hline Tribute & 1RS:1AL & no & $5+10$ & insensitive & no \\
\hline VAVA11DH-P46xTrib-103 & non-1RS & no & $5+10$ & insensitive & no \\
\hline VAVA11DH-P46xTrib-99 & non-1RS & no & $5+10$ & insensitive & no \\
\hline VAVA11DH-P46xTrib-28 & non-1RS & no & $5+10$ & insensitive & no \\
\hline
\end{tabular}

according to Method 55-11.02 (American Association of Cereal Chemists, 1999) with a modification of flour weight to $1 \mathrm{~g}$ as described by Kweon, Slade, and Levine (2011). Lactic acid solvent retention capacity predicts gluten strength, while $\mathrm{Na}_{2} \mathrm{CO}_{3}$ estimates the damaged starch content. Sugar-snap cookie baking test of flour was performed according to Method 10-52.02 (American Association of Cereal Chemists, 1999). The diameters (cm) of two cookies per sample were measured with the Mitutoyo Absolute Digimatic Caliper to generate a mean cookie diameter $(\mathrm{cm})$. Cookie top grade for both cookies was graded visually for surface appearance, from worst to best on a scale of $1-10$.

\section{$2.4 \quad$ Statistical analysis}

An augmented single replicate test design was used, with eight checks including both parents replicated throughout the test at least twice; each site-year was considered a block. This was done because of limited seed sources, the cost of measuring end-use quality, and because milling and baking traits are highly heritable, with consistent results between site-years (Guttieri \& Souza, 2003; Guttieri, Bowen, Gannon, O’Brien, \& Souza, 2001; Souza et al., 2012). Therefore, numerous replicates are not needed to determine significant differences. The augmented complete block design (ACBD-R) with $\mathrm{R}$ for Windows Version 4.0 was used to analyze the three site-years individually (Table 4) and as multiyear environments (Table 2) (Rodriquez, Alvarado, Pacheco, \& Burgueno, 2018). Best linear unbiased predictors (BLUP) of each DH line and the checks were generated along with least significant differences $(p=.05)$ for use in line comparisons.

\section{3 | CHARACTERISTICS}

Pioneer 26R46 is considered to have very good milling and baking quality. It was consistently the top-performing check or parent in this test. An individual line was considered to have exceptional milling and baking quality if it consistently performs similar to or better than Pioneer 26R46.

\section{1 | Kernel morphology}

Kernel weight (mg) for VA11DH-P46xTrib-103 and VA11DH-P46-Trib-99 was lower $(p<.05)$ than that of Pioneer 26R46, while VA11DH-P46xTrib-28 had a similar kernel weight in the multi-environment comparison. All three DH lines had kernel diameters $(\mathrm{mm})$ lower $(p<.05)$ than Pioneer 26R46, while test weight $\left(\mathrm{kg} \mathrm{hl}^{-1}\right)$, kernel hardness, and protein $\left(\mathrm{g} \mathrm{kg}^{-1}\right)$ were similar to Pioneer 26R46 (Table 2).

\section{2 | Milling and baking performance}

Flour yield $\left(\mathrm{g} \mathrm{kg}^{-1}\right)$ and cookie diameter $(\mathrm{cm})$ are two primary quality parameters considered and used routinely by breeders in identification of breeding lines with better end-use quality. Cookie diameter and flour yield are positively correlated, while both are negatively correlated with flour protein $\left(\mathrm{g} \mathrm{kg}^{-1}\right)$ and solvent retention capacity traits (Knott, Van Sanford, \& Souza, 2009; Souza et al., 2012). This is due in part to the endosperm being released more easily from the bran during milling in wheat cultivars that have higher flour extraction. Starch granules suffer less damage during milling if the endosperm is more easily disintegrated into fine flour particles, as observed in wheat grain of low kernel hardness. Wheat cultivars having lower break flour extraction exhibit greater starch damage due to the extra shearing and crushing of endosperm particles during milling (Smith et al., 2011). Sodium carbonate solvent retention capacity $\left(\mathrm{g} \mathrm{kg}^{-1}\right)$ is a measure of damaged starch, while lactic acid solvent retention capacity $\left(\mathrm{g} \mathrm{kg}^{-1}\right)$ is a measure of gluten strength, both of which tend to increase as kernel hardness and protein increase. Soft red winter wheat cultivars having high flour yield and lower flour protein tend to have good cookie baking performance, which is what flour millers and bakers typically 


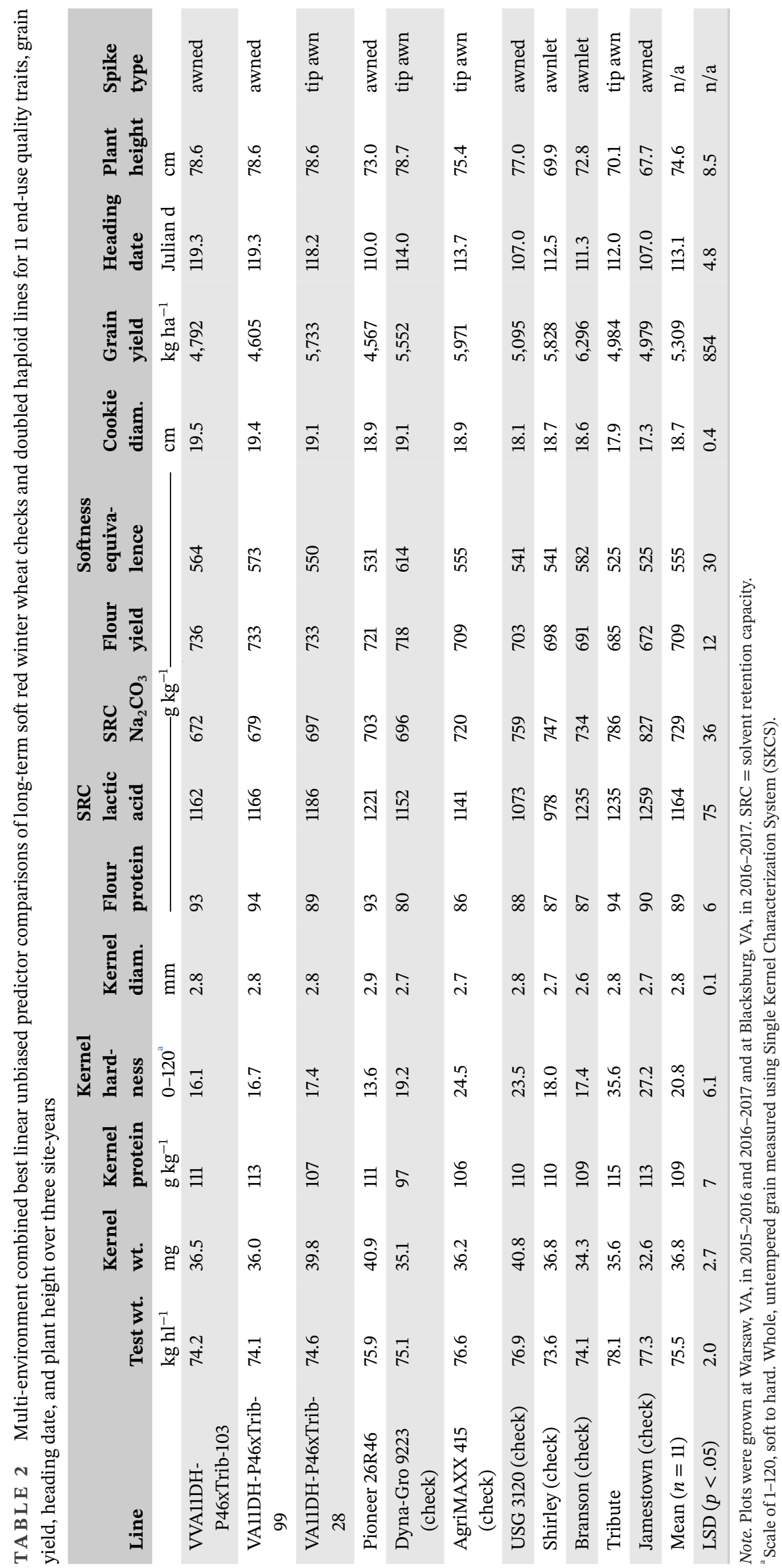


TA B L E 3 Winter wheat trial management by site-year

\begin{tabular}{|c|c|c|c|}
\hline Location & Warsaw, VA & Warsaw, VA & Blacksburg, VA \\
\hline Coordinates & $37^{\circ} 59^{\prime} 54^{\prime \prime} \mathrm{N}, 76^{\circ} 46^{\prime} 23^{\prime \prime} \mathrm{W}$ & $37^{\circ} 59^{\prime} 33^{\prime \prime} \mathrm{N}, 76^{\circ} 46^{\prime} 24^{\prime \prime} \mathrm{W}$ & $36^{\circ} 40^{\prime} 59^{\prime \prime} \mathrm{N}, 76^{\circ} 45^{\prime} 38^{\prime \prime} \mathrm{W}$ \\
\hline Year & 2015-2016 & 2016-2017 & 2016-2017 \\
\hline Elevation, m & 36 & 40 & 518 \\
\hline Area harvested, m & 1.5 by 2.7 & 1.5 by 2.7 & 1.5 by 2.7 \\
\hline \multirow{2}{*}{$\begin{array}{l}\text { Fertilizer } \\
\text { applications }^{\mathrm{a}}\end{array}$} & $\begin{array}{l}33.6 \mathrm{~kg} \mathrm{ha}^{-1} \mathrm{~N}(12001.5), \\
\text { 14 Dec. }\end{array}$ & $\begin{array}{l}33.6 \mathrm{~kg} \mathrm{ha}^{-1} \mathrm{~N}(12001.5), \\
\text { 7 Dec. }\end{array}$ & $\begin{array}{l}28.0 \mathrm{~kg} \mathrm{ha}^{-1} \text { UAN } 30-0-0, \\
17 \mathrm{Feb} \text {. }\end{array}$ \\
\hline & $\begin{array}{l}33.6 \mathrm{~kg} \mathrm{ha}^{-1} \mathrm{~N}(12001.5), \\
12 \mathrm{Feb} .\end{array}$ & $\begin{array}{l}33.6 \mathrm{~kg} \mathrm{ha}^{-1} \mathrm{~N}(12001.5) \\
\text { 9 Feb. }\end{array}$ & $\begin{array}{l}67.3 \mathrm{~kg} \mathrm{ha}^{-1} \text { UAN 30-0-0, } \\
24 \mathrm{Mar}^{\text {. }}\end{array}$ \\
\hline \multirow{2}{*}{$\begin{array}{l}\text { Pesticide } \\
\text { applications, ml } \\
\text { ha }^{-1}\end{array}$} & Prosaro, 95.7, 3 May & Prosaro, 95.7, 1 May & Tilt, 47.9, 27 Mar. \\
\hline & & Fitness, 47.9, 11 Apr. & Tilt, 47.9, 30 May \\
\hline $\begin{array}{l}\text { Growth regulator, } \mathrm{ml} \\
\mathrm{ha}^{-1}\end{array}$ & $\begin{array}{l}\text { Palisade EC, } 95.7 \text {, } \\
14 \text { Mar. }\end{array}$ & $\begin{array}{l}\text { Palisade EC, 95.7, } \\
17 \text { Mar. }\end{array}$ & $\begin{array}{l}\text { Palisade EC, 95.7, } \\
27 \text { Mar. }\end{array}$ \\
\hline Tillage & conventional & conventional & conventional \\
\hline Planting date & 22 Oct. 2015 & 23 Oct. 2016 & 11 Oct. 2016 \\
\hline Harvest date & 20 June 2016 & 21 June 2017 & 22 June 2017 \\
\hline
\end{tabular}

${ }^{a}$ Fertilizers as $\mathrm{N}-\mathrm{P}_{2} \mathrm{O}_{5}-\mathrm{K}_{2} \mathrm{O}$. UAN, urea- $\mathrm{NH}_{4} \mathrm{NO}_{3} \cdot 12001.05$ is a $28 \%$ urea and $\mathrm{NH}_{4} \mathrm{NO}_{3}$ product used a an $\mathrm{N}$ fertilizer.

TA B L E 4 Least significant differences from best linear unbiased predictor of single replicated tests by site-year for comparison of soft red winter wheat checks (ck) and doubled haploid lines for flour yield and cookie diameter

\begin{tabular}{|c|c|c|c|c|c|c|}
\hline \multirow[t]{2}{*}{ Flour yield } & \multicolumn{6}{|c|}{ Cookie diameter } \\
\hline & $\begin{array}{l}\text { Warsaw } \\
2016\end{array}$ & $\begin{array}{l}\text { Warsaw } \\
2017\end{array}$ & $\begin{array}{l}\text { Blacksburg } \\
2017\end{array}$ & $\begin{array}{l}\text { Warsaw } \\
2016\end{array}$ & $\begin{array}{l}\text { Warsaw } \\
2017\end{array}$ & $\begin{array}{l}\text { Blacksburg } \\
2017\end{array}$ \\
\hline VA11DH-P46xTrib-103 & 724 & 754 & 737 & 19.4 & 19.5 & 20.0 \\
\hline VA11DH-P46xTrib-99 & 720 & 755 & 730 & 19.0 & 19.6 & 19.9 \\
\hline Dyna-Gro 9223 (ck) & 705 & 728 & 720 & 18.3 & 19.2 & 19.8 \\
\hline AgriMAXX 415 (ck) & 703 & 712 & 713 & 18.8 & 18.9 & 19.0 \\
\hline USG 3120 (ck) & 695 & 714 & 698 & 17.3 & 18.6 & 18.3 \\
\hline Shirley (ck) & 687 & 706 & 700 & 18.3 & 18.9 & 19.1 \\
\hline Mean $(n=11)$ & 701 & 719 & 709 & 18.2 & 18.9 & 19.0 \\
\hline $\operatorname{LSD}(p<.05)$ & 11 & 8 & 8 & 0.6 & 0.4 & 0.4 \\
\hline
\end{tabular}

desire for pastry products (Gwirtz, Willyard, \& McFall, 2007).

By site-year, BLUP analysis indicates that all three DH lines had higher $(p<.05)$ flour yields at Blacksburg 2017 and Warsaw 2017 site-years than Pioneer 26R46 and were similar at Warsaw 2016. Lines VA11DH-P46xTrib-103 and VA11DH-P46xTrib-99 had higher $(p<.05)$ cookie diameters at Warsaw 2016 and Blacksburg 2017 than Pioneer 
TA B L E 5 Fusarium head blight (FHB) severity, Fusarium damaged kernels (FDK), and deoxynivalenol (DON) content in selected doubled haploid lines and parents evaluated across Arkansas (Fayetteville and Newport), Kentucky (Lexington), North Carolina (Kinston), and Virginia (Blacksburg) in 2013 and 2014 harvests

\begin{tabular}{|c|c|c|c|}
\hline \multirow[t]{2}{*}{ Line } & $\begin{array}{l}\text { FHB } \\
\text { severity }\end{array}$ & FDK & DON \\
\hline & \multicolumn{2}{|c|}{ - $\%$} & $\mathrm{mg} \mathrm{kg}^{-1}$ \\
\hline VA11DH-P46xTrib-28 & 41.5 & 47.5 & 18.4 \\
\hline VA11DH-P46xTrib-99 & 41.6 & 45.1 & 23.5 \\
\hline Mean $(n=5)$ & 46.9 & 48.9 & 19.9 \\
\hline $\operatorname{LSD}(p<.05)$ & 6.1 & 9.9 & 3.6 \\
\hline
\end{tabular}

26R46 and were similar at Warsaw 2017. Line VA11DHP46xTrib-28 had similar cookie diameters as Pioneer 26R46 at all site-years (Table 4).

The multi-environment combined BLUP results indicate that all three DH lines are similar to Pioneer 26R46 for flour protein and both solvent retention capacities (lactic acid and $\mathrm{NA}_{2} \mathrm{CO}_{3}$ ). Line VA11DH-P46xTrib-103 was higher $(p<.05)$ than Pioneer 26R46 for flour yield and cookie diameter. Line VA11DH-P46xTrib-103 was higher $(p<.05)$ for softness equivalence and cookie diameter than Pioneer $26 \mathrm{R} 46$.

\section{3 | Grain yield and plant characteristics}

Line VA11DH-P46xTrib-28 had higher $(p<.05)$ grain yields than Pioneer 26R46. Lines VA11DH-P46xTrib-103 and VA11DH-P46xTrib-99 had grain yields similar to Pioneer 26R46. All three DH lines headed 8-9 d later than Pioneer 26R46 and were $5.6 \mathrm{~cm}$ taller. Spikes of VA11DHP46xTrib-28 have short tip awns, while spikes of VAllDHP46xTrib-99 and VA11DH-P46xTrib-103 are awned.

\section{4 | Fusarium head blight}

Data for reaction to FHB was previously collected on the three $\mathrm{DH}$ lines and both parents across five locations during 2013 and 2014: Arkansas (Fayetteville and Newport), Kentucky (Lexington), North Carolina (Kinston), and Virginia (Blacksburg). All three lines appear to fit within the normal distribution of progeny, being more susceptible than Tribute and less than or as susceptible as Pioneer 26R46 for FHB severity, Fusarium damage kernels, and deoxynivalenol (DON) content. The average FHB severity, Fusarium damage kernels, and DON concentration are shown in Table 5. All three DH lines had lower $(p>.05)$ FHB severity than Pioneer 26R46.
Lines VA11DH-P46xTrib-28 and VA11DH-P46xTrib-99 had fewer $(p>.05)$ Fusarium damage kernels than Pioneer 26R46. Line VA11DH-P46xTrib-103 was similar to Pioneer 26R46 for Fusarium damage kernels. Only line VA11DHP46xTrib-28 had lower $(p>.05)$ DON content than Pioneer 26R46, while the other two DH lines were similar to Pioneer 26R46 for DON.

\section{5 | Seed purification and increase}

Sixty-four individual plants of each DH line were planted, vernalized for $7 \mathrm{wk}$, transplanted into larger pots, grown to maturity in a greenhouse, and harvested to produce a pure seed source. Variant or off-type plants were discarded prior to harvest, and seed from the remaining plants deemed to be uniform and true to type was bulked to form the breeder seed.

\section{4 | AVAILABILITY}

Small seed quantities of all three lines will be made available upon request for breeding purposes and can be obtained from the Small Grains Breeding and Genetics group at Virginia Tech. Seed of lines VA11DH-P46xTrib-28, VA11DH-P46xTrib-99, and VA11DH-P46xTrib-103 has been deposited with the USDA National Plant Germplasm System, where it will be available $5 \mathrm{yr}$ after publication of this article.

\section{CONFLICT OF INTEREST}

The authors declare no conflict of interest.

\section{O R C I D}

Nicholas A. Meier (1) https://orcid.org/0000-0003-42055184

Carl A. Griffey (1D) https://orcid.org/0000-0003-4196-7982 


\section{REFERENCES}

American Association of Cereal Chemists. (1999). AACC approved methods of analysis (11th ed.). St. Paul, MN: Cereals \& Grains Association.

Brann, D., Holshouser, D., \& Mullins, G. (2000). Agronomy handbook (Publ. no. 424-100). Blacksburg, VA: Virginia Cooperative Extension.

Breseghello, F., \& Sorrells, M. E. (2006). Association mapping of kernel size and milling quality in wheat (Triticum aestivum L.) cultivars. Genetics, 172, 1165-1177. https://doi.org/10.1534/genetics.105. 044586

Cabrera, A., Guttieri, M., Smith, N., Souza, E., Sturbaum, A., Hua, D., ... Sneller, C. (2015). Identification of milling and baking quality QTL in multiple soft wheat mapping populations. Theoretical and Applied Genetics, 128, 2227-2242. https://doi.org/10.1007/s00122015-2580-3

Finney, P., \& Andrews, L. (1986). Revised microtesting for soft wheat quality evaluation. Cereal Chemistry, 63, 177-182.

Griffey, C., Rohrer, W., Pridgen, T., Brooks, W., Chen, J., Wilson, J., ... Whitcher, L. (2005). Registration of 'Tribute' wheat. Crop Science, 45, 419-421. https://doi.org/10.2135/cropsci2005.0419

Guttieri, M. J., Bowen, D., Gannon, D., O’Brien, K., \& Souza, E. (2001). Solvent retention capacities of irrigated soft white spring wheat flours. Crop Science, 41, 1054-1061. https://doi.org/10.2135/ cropsci2001.4141054x

Guttieri, M. J., \& Souza, E. (2003). Sources of variation in the solvent retention capacity test of wheat flour. Crop Science, 43, 1628-1633. https://doi.org/10.2135/cropsci2003.1628

Gwirtz, J., Willyard, M., \& McFall, K. (2007). Wheat quality in the United States of America. In L. Popper, W. Schäfer, \& W. Freund (Eds.) Future of flour: A compendium of flour improvement (pp. 1742). Ahrensburg, Germany: Agrimedia.

Kiszonas, A., \& Morris, C. (2017). Wheat breeding for quality: An historical review. Cereal Chemistry, 95, 17-34.

Knott, C. A., Van Sanford, D. A., \& Souza, E. J. (2009). Genetic variation and the effectiveness of early-generation selection for soft winter wheat quality and gluten strength. Crop Science, 49, 113119. https://doi.org/10.2135/cropsci2008.05.0290

Kweon, M., Slade, L., \& Levine, H. (2011). Solvent retention capacity (SRC) testing of wheat flour: Principles and value in predicting flour functionality in different wheat-based food processes and in wheat breeding-A review. Cereal Chemistry, 88, 537-552. https://doi.org/10.1094/CCHEM-07-11-0092

Li, Y., Song, Y., Zhou, R., Branlard, G., \& Jia, J. (2009). Detection of QTLs for bread-making quality in wheat using a recombinant inbred line population. Plant Breeding, 128, 235-243. https://doi. org/10.1111/j.1439-0523.2008.01578.x

Posner, E. S., \& Hibbs, A. N. (2005). Wheat flour milling (2nd ed.). St. Paul, MN: Cereals \& Grains Association.

Rodriquez, F., Alvarado, G., Pacheco, A., \& Burgueno, J. (2018). $A C B D-R$ augmented complete block design with $R$ for Windows Version 4.0. CIMMYT Research Data \& Software Repository Network, V6.

Smith, N., Guttieri, M., Souza, E., Shoots, J., Sorrells, M., \& Sneller, C. (2011). Identification and validation of QTL for grain quality traits in a cross of soft wheat cultivars Pioneer Brand 25R26 and Foster. Crop Science, 51, 1424-1436. https://doi.org/10.2135/cropsci2010. 04.0193

Souza, E. J., Sneller, C., Guttieri, M. J., Sturbaum, A., Griffey, C., Sorrells, M., ... Van Sanford, D. (2012). Basis for selecting soft wheat for end-use quality. Crop Science, 52, 21-31. https://doi.org/10.2135/ cropsci2011.02.0090

How to cite this article: Meier NA, Malla S, Oakes JC, et al. Registration of three soft red winter wheat germplasm lines with exceptional milling and cookie baking performance. J. Plant Regist. 2020;1-7. https://doi.org/10.1002/plr2.20055 